IZA DP No. 5995

Re-examining the Impact of Dropping out on Criminal and Labor Outcomes in Early Adulthood

David Bjerk

September 2011

Forschungsinstitut zur Zukunft der Arbeit Institute for the Study of Labor 


\title{
Re-examining the Impact of Dropping Out on Criminal and Labor Outcomes in Early Adulthood
}

\author{
David Bjerk \\ Claremont McKenna College \\ and IZA
}
Discussion Paper No. 5995
September 2011

\author{
IZA \\ P.O. Box 7240 \\ 53072 Bonn \\ Germany \\ Phone: +49-228-3894-0 \\ Fax: +49-228-3894-180 \\ E-mail: iza@iza.org
}

\begin{abstract}
Any opinions expressed here are those of the author(s) and not those of IZA. Research published in this series may include views on policy, but the institute itself takes no institutional policy positions.

The Institute for the Study of Labor (IZA) in Bonn is a local and virtual international research center and a place of communication between science, politics and business. IZA is an independent nonprofit organization supported by Deutsche Post Foundation. The center is associated with the University of Bonn and offers a stimulating research environment through its international network, workshops and conferences, data service, project support, research visits and doctoral program. IZA engages in (i) original and internationally competitive research in all fields of labor economics, (ii) development of policy concepts, and (iii) dissemination of research results and concepts to the interested public.
\end{abstract}

IZA Discussion Papers often represent preliminary work and are circulated to encourage discussion. Citation of such a paper should account for its provisional character. A revised version may be available directly from the author. 


\section{ABSTRACT \\ Re-examining the Impact of Dropping Out on Criminal and Labor Outcomes in Early Adulthood ${ }^{*}$}

This paper shows that while high school dropouts fare far worse on average than otherwise similar high school completers in early adulthood outcomes such as success in the labor market and future criminal activity, there are important differences within this group of dropouts. Notably, those who feel "pulled" out of school (i.e, they say they dropped out of school to work or take care of family) do similarly with respect to labor market and criminal outcomes in their early twenties to individuals with similar pre-dropout characteristics who complete high school. It is only those who feel they are more "pushed" out of school (i.e, they say they drop out for other reasons including expulsion, poor grades, moving, and not liking school) who do substantially worse than otherwise similar high school completers. These results suggest that any detrimental impacts from dropping out of school arise primarily when the drop out does not have a plan for how to use his time after dropping out.

JEL Classification: J31, K42, I21

Keywords: dropouts, crime, wages, earnings, idleness

Corresponding author:

David Bjerk

Robert Day School of Economics and Finance

Claremont McKenna College

313 Bauer Center North

500 E. Ninth St.

Claremont, CA 91711

USA

E-mail: david.bjerk@cmc.edu

Thanks to Joni Hersch, Paul Heaton, Gordon Dahl and seminar participants at Vanderbilt Law School, UC-Santa Cruz, and the Southern California Conference on Applied Microeconomics for helpful suggestions on this project. 


\section{I - Introduction}

It has been well-documented that individuals who drop out of school before twelfth grade have much poorer adult outcomes in the labor market (Rumberger 1987) and are involved in more criminal activity and are more frequently arrested than individuals who finish high school (Thornberry, Moore, and Christenson 1985). Indeed, a simple look at Bureau of Labor Statistics data from the $3^{\text {rd }}$ quarter of 2008 shows that median weekly earnings for employed males with high school degrees but no college are over 40 percent higher than such earnings for employed male dropouts. Similarly, during the same time period, the labor force participation rate for all individuals with high school degrees but no college is over 50 percent higher than the analogous rate for individuals who did not complete high school.

However, it is not necessarily the case that the fewer years of education dropouts receive is the primary cause of such poorer outcomes. One obvious concern is that individuals who drop out of school before graduating are quite different from those who stay, and it is this heterogeneity between dropouts and graduates, not the additional education per say, that accounts for a substantial portion of the outcomes differences between the two groups. For example, those who drop out of high school are generally lower academic achievers, have lower motivation, have lower expectations about the labor market payoffs to graduating, incur greater disutility from school, and are of lower socioeconomic status, than those who choose to stay (Eckstein and Wolpin 1999). Therefore, simply comparing the later-life labor market and criminal outcomes for dropouts versus high school completers will not necessarily reveal how high school dropouts would have fared if they had stayed in school longer, or how high school completers would have fared if they had dropped out.

To overcome this issue, a variety of papers have used differences in mandatory schooling laws across time and place as plausibly exogenous sources of variation in schooling and have still found very large impacts on future labor market outcomes and criminal behavior by keeping marginal students in school longer (Harmon and Walker 1995, Chevalier et al. 2004, Oreopolous 2003, 2008, Angrist and Krueger 1991, Lochner and Moretti 2004). 
The results in these papers provide relatively convincing evidence that, on average, keeping kids on the verge of dropping out in school a few months longer can have long lasting positive impacts on their behavior. Given these results, some scholars, notably Oreopolous (2008), argue required schooling laws should be increased to 17 or 18 years old. However, before such conclusions can be made, more needs to be known about where these effects are coming from. Namely, would most all students on the verge of dropping out likely benefit from a little more schooling, or are such benefits likely to only apply to particular subsets of the dropout population? Relatedly, why do a few months more schooling appear to lead to such large long-term benefits for at least some of those who are on the verge of dropping out?

In addressing these questions, I primarily explore whether there are important heterogeneities within the group of dropouts that correlate to their early adult outcomes. Specifically, I examine whether the reason individuals give for dropping out of school is correlated with labor market and criminal outcomes several years after dropping out. Individuals drop out of school for a variety of reasons, some of which have been described as push factors (e.g., suspension, bad grades, moved away, didn't like it) and others pull factors (e.g., to work, take care of family). The primary question of interest here pertains to the extent to which these different reasons for dropping out relate to differential outcomes in their early adulthood. Namely, is there evidence that those who had an active plan for what they are going to do after dropping out---i.e., those who felt pulled out of school---do better than those who did not have an active plan for what to do after dropping out---i.e., those who felt pushed out of school? The answer to this question will help us better understand who would benefit most from being forced to stay in school longer, and moreover, as I discuss below, may actually help us understand why such additional may have such large long-term impacts for some youth.

To explore these issues, I use data from the National Longitudinal Survey of Youth 1997 and stratify high school dropouts into four distinct groups based on the reason they gave for dropping out---(i) To work or take care of family, (ii) Because they disliked school, (iii) Behavioral problems (e.g., incarceration, drugs, expulsion), (iv) "Other passive" reasons (which primarily includes "outside" factors such as school being too dangerous, moved away from school/school too far to get to, financial difficulties). I 
argue that the first of these categories represents pull factors, or arguably a rational calculation to leave school, as those who said they dropped out to work or take care of family members at least thought they had an active plan regarding how to use their time upon leaving school (whether or not this turned out to be true in actuality). By contrast, I would argue that those who said they dropped out due to "behavioral" reasons and "other passive" reasons are more aptly described as being pushed from school as they likely did not make an active calculation that leaving school was how to best use their time, but rather their circumstances made it difficult for them to remain in school. Finally, those who dropped out because they said they "disliked" school may lie somewhere in between. While such individuals may not have had a particularly focused plan regarding what to do with their time upon dropping out, they still may have perceived that they were not benefiting from the time spent in school relative to what else they could try to be doing with that time.

Not surprisingly, the results from this analysis confirm that, overall, high school dropouts indeed have substantially lower earnings in their early twenties and participate in much more crime in their early twenties than those who continue through to twelfth grade but otherwise have similar pre-dropout achievement and background characteristics. However, I also find that there are important heterogeneities in such outcomes for dropouts by the reason given for dropping out. Not surprisingly, those high school dropouts who drop out for push reasons (including expulsion, low grades, substance problems, and legal problems), or other "passive" reasons (moved away, health problems) do fare far worse with respect to their labor market outcomes and criminal behavior in their early twenties than high school completers who had similar pre-dropout characteristics. Those who say they dropped out because they did not like school do only somewhat worse in the labor market and appear to be only somewhat more criminally active in their early twenties than otherwise similar high school completers. Finally, and most notably, individuals who say they dropped out to work or take care of family members (i.e., dropped out due to pull factors) actually earn the same amount and commit no more crime in their early twenties than those who continue through to twelfth grade with similar prior background, achievement, and behavioral characteristics. In other words, this group of dropouts who say they dropped out due to an active plan of 
how to alternatively use their time appear to face minimal negative impacts from such a decision a few years hence relative to otherwise similar high-school completing peers.

These results suggest that the findings of the previous literature cited above---that suggest requiring high school students to stay in school a few months longer has substantial longer-term benefits for those on the verge of dropping out---arise primarily through the effect such requirements have on these individuals who would drop out for the push factor categories I discussed above. Those who drop out but have a plan regarding what they are going to do with their time, or in other words feel pulled out of school, do not appear to be substantially hurt by their decision to drop out. This suggests that what might be of primary importance to late adolescents on the verge of dropping out is an active and productive use of their time. Hence, while the increasing the age of required schooling for all students can be beneficial on average for the future outcomes for many individuals on the verge of dropping out, such policies may be unduly costly and poorly targeted, as some students appear to incur no subsequent outcome consequences from dropping out of high school. Allowing exceptions to such increases in the mandatory age for things like work and apprenticeship programs may be a preferable alternative.

\section{II - Related Literature}

As discussed above, one of the primary issues to overcome in attempting to quantify the extent to which dropping out of school affects future outcomes is the nonrandomness regarding who chooses to drop out. Specifically, those who drop out would likely have worse future outcomes than those who do not, even if the dropouts were to have stayed in school.

To attempt to overcome this selection issue, several recent prominent studies have used very plausible "natural experiment" type research designs to show that keeping potential high school dropouts in school longer can indeed have dramatic causal effects on the future outcomes of many youths. For example, using the variation in compulsory schooling ages across states, Lochner and Moretti (2004) find that raising the compulsory schooling age by one year lowers the probability of incarceration later in life by 0.10 percentage points for whites and 0.37 percentage points for blacks. They argue that the 
social savings from crime reduction associated with a one-percent increase in high school completion rates would save as much as $\$ 1.4$ billion, or $\$ 2,100$ per additional male high school graduate.

A variety of other studies also use different aspects of compulsory schooling laws to examine the long-term impact of increasing the schooling of potential dropouts on earnings. For example, Angrist and Krueger (1991) use season of birth combined with compulsory schooling laws as a source of exogenous variation in years of schooling across individuals. They motivate this approach by arguing that children born in different months start school at different ages, but most states only require students to stay in school until their sixteenth birthday. This means that at their sixteenth birthday, some students can have up to a year more of education than others. Using this source of variation in years of education at the age of dropping out, Angrist and Krueger find that those males forced to attend one year of further school due to compulsory schooling laws increase their future earnings by about 7.5 percent.

Several other researchers (Harmon and Walker 1995, Chevalier et al. 2004, and Oreopolous 2003, 2008, Anderson 2010) have used time and/or regional variation in compulsory schooling ages to examine the labor market effects of keeping a potential dropout in school for a longer time period. These studies also find relatively dramatic labor market payoffs to keeping such marginal students in school a year longer. Indeed, in summarizing his findings, Oreopolous (2008, pp 22) concludes "the results presented in this paper speak in favor of supporting an increase of the school leaving age to 17 or 18."

As discussed in the introduction, while such findings are certainly persuasive that keeping some marginal students in school longer can have substantially positive impacts on future outcomes for some of them, important questions remain. For example, would all potential dropouts benefit from a few months more schooling, or should we expect only a particular subset of potential dropouts to benefit from more mandatory schooling? Relatedly, why does keeping such marginal students in school a little while longer have such dramatic effects on their future outcomes? After all, the group of youth affected by increases the mandatory age of schooling is likely a population that engages very little in 
their class work at school. Therefore, it is unclear why their future outcomes are so affected by a few more months of class time.

As stated above, there might be important heterogeneities among those who drop out of school. For some, dropping out is the culmination of a process that likely started years before, while for others it may happen quite suddenly due to a change in life circumstances (Alexander et al. 1997). Moreover, dropping out of school is often a process, with many students leaving and returning to school multiple times (Chuang 1997; Entwistle et al. 2004).

However, most relevant to this study, among individuals classified as dropouts, there is considerable variation in the proximate reason or reasons individuals give for dropping out of school (Rumberger 1987). As argued by other researchers, many of these reasons can be often be classified as pull factors, or factors such that the individual says he dropped out in order to do more of a particular activity such as working for pay or taking care of family members, while others can be classified as push factors, where the circumstances an individual found himself in made school no longer tenable and was in some sense pushed out, which could include reasons such as expulsion, residential moves, poor performance, or legal problems (Stearns and Glennie 2006, McNeal 1997, Mihalic and Elliot 1997, Fine 1986, Jordan et al. 1996).

The work here builds particularly on Jarjoura (1993) and Sweeten et al. (2009) who look at how criminal behavior varies by reason given for dropping out. Sweeten et al. (2009) primarily use the reason given for dropping out as a way to examine the implications of "identity" theory with respect to crime. Given this interest, their analysis differs from that done below in that they stratify and control for their "reasons for dropping out" in substantially different ways than done here. Moreover, Sweeten et al. (2009) use an individual fixed-effects strategy, essentially looking at how criminal behavior differed for an individual in the time just after dropping out relative to when in school. This is in contrast to the analysis done here which attempts to look at both criminal and labor market behavior when individuals are in their early twenties, several years subsequent to the dropout decision.

\section{III - Analysis}


The data used for this analysis comes from the National Longitudinal Survey of Youth 1997 (NLSY97). The NLSY97 consists of a survey of a nationally representative sample of approximately 9,000 youths who were 12 to 16 years old as of December 1996 conducted under the auspices of the Bureau of Labor Statistics. Those youth selected for the NLSY97 have been surveyed annually since 1997 regarding their labor market experiences, education, as well as criminal activity and arrests.

As discussed above, defining dropouts can be difficult, as many students leave and return to school multiple times. This is certainly a complicated issue when studying dropouts. However, for the purposes of this analysis, "Dropouts" are simply defined as individuals who had only attended up to grade 11 or lower by the age of 19 and had no high school diploma by age 19. "High School Completers" are then defined as either having reported a high school diploma by age 19 or having attended, though not necessarily completed, grade twelve by age 19. See Data Appendix for additional detail.

This definition means there are some individuals defined to be high school completers who did not actually receive a high school degree by age 19, and/or who dropped out at one point but returned to enroll in twelfth grade by age 19. Relatedly, those who earn GEDs can be in either category, with those who left school before grade 12 and subsequently earned a GED being treated by as dropouts, and those who stayed in school up to grade 12 before leaving and earning their GED being treated as completers. However, since the interest of this paper is on understanding the effects of additional time in school (as motivated by the studies examining the effect of keeping marginal students in school a little longer), not the credentialing effects of a high school degree or a GED, this definition seems appropriate.

The sample is limited to males who had valid responses for why they left school as well as valid AFQT scores. ${ }^{1}$ While understanding the relationship between reason for dropping out and subsequent outcomes for females is also of interest, I limit my analysis to males for a couple of reasons. First, pregnancy and childbirth necessarily can interfere with school attendance, making the issue of when to categorize a female as a dropout even more difficult than it is for males. Second, both female labor supply and female

\footnotetext{
${ }^{1}$ The AFQT is a mathematics and language achievement test used by the Armed forces in assigning jobs to new recruits that is given to the vast majority of NSLY97 respondents. The scores are normed to account for age.
} 
criminal behavior follow very different paths than such processes do for men, and moreover, there is more heterogeneity (at least with respect to labor supply) for females on average than for males. For these reasons I would argue that it would be more appropriate to analyze females in a separate study from males in this context.

It should also be noted that excluding those without AFQT scores from the sample excludes roughly 20 percent of the NLSY respondents. Moreover, those without AFQT scores do not simply appear to be a random subsample. For example, AFQT scores are missing for a higher fraction of black and Hispanic respondents than whites, and are missing from a higher fraction of urban residents than rural residents. While this is a potential concern to the external validity of the subsequent results, I do not feel this concern is overly large for a few reasons. First, the qualitative results remain essentially similar if those with missing AFQT scores are included and then a dummy for missing AFQT scores is included in all regressions (results available from author upon request). Second, race dummies and urban residence dummies are used in all specifications, which will pick up some of the sample selection issues that arise due to the non-randomness of the missing scores. Third, past studies that use NLSY samples restricted to only those with valid $\mathrm{AFQT}$ scores find similar aggregate results to those that use more representative samples. For example, using a sample of only those who had valid AFQT scores in the NLSY79, Neal and Johnson (1996) found an unconditional log wage gap between black and white male workers of about 0.24 circa 1990. This is certainly very comparable to Chandra's (2000) finding that black male workers earned wages approximately 75 percent of white male worker wages according to the 1990 U.S. Census data.

The labor market outcomes focus on each individual's annual labor market earnings as reported in the 2006 survey wave and each individual's reported wage rate in 2006. When interviewed in the 2006 wave, respondents ranged in age from 20 to 26, with the vast majority being between 21 and 25. If earnings or wage rate was not reported for 2006 due to non-interview, I use the inflation adjusted reported values from 2005.

The criminal activity outcomes include total number of property crimes committed in the previous year (as reported in the 2003 wave), total number of drug sales in the previous year (as reported in the 2003 wave), and total number of arrests (as 
reported in the 2003 wave). Criminal participation data was taken from the 2003 wave of the NLSY 97 because after 2003 only those who had been previously arrested were asked about their criminal participation.

As expected, Table 1 confirms that among the NSLY97 respondents, high school dropouts indeed have substantially worse labor market and criminal participation outcomes than high school completers on all of the outcome dimensions examined here.

\section{III(a) - Controlling for Family Environment, Achievement, and Behavioral}

\section{Characteristics}

As a first step, it is important to determine how much of the outcome gaps shown in Table 1 between high school dropouts and high school completers can be accounted for by differences in several key pre-dropout characteristics. In other words, how much of the differences in outcomes can be explained by the fact that high school dropouts have a variety of pre-dropout characteristics that make them much more likely to have poor future outcomes than high school completers?

Table 2 reveals that indeed, high school dropouts differ from high school completers on several important pre-dropout dimensions, including family environment (family income in 1997, household composition in 1997, mother gave birth while in her teens, region of residence at age 12 , urban residence at age 12, presence of gangs in school), academic achievement (as measured by AFQT scores and grades in $8^{\text {th }}$ grade), and behavioral characteristics (suspensions prior to age 16, delinquency index in 1997, and whether they smoked marijuana prior to age 16).

The results shown in Table 3 reveal that these differences in observable predropout characteristics indeed account for a substantial portion of the outcome gaps between high school dropouts and high school completers. In particular, Table 3 presents the key results of several regressions of the form

$\mathrm{Y}_{\mathrm{i}}=\alpha+\beta_{\mathrm{D}} *$ Dropout $_{\mathrm{i}}+\boldsymbol{\beta}_{\mathbf{X}} * \mathbf{X}_{\mathbf{i}}+\varepsilon_{\mathrm{i}}$ 
where $Y_{i}$ is some early adulthood outcome of interest, Dropout $t_{i}$ is an indicator for the individual being a dropout, $\mathbf{X}_{\mathrm{i}}$ is a vector of individual characteristics, and $\varepsilon_{\mathrm{i}}$ is the individual residual term.

The top panel of Table 3 shows the estimated coefficients on the dropout dummy variable from five different regression specifications for each of three different labor market outcomes of interest. In the first specification for each outcome in Table 3 the vector $\mathbf{X}_{\mathrm{i}}$ includes only birth year dummies. The $\mathbf{X}_{\mathrm{i}}$ vector in the second specification for each outcome further includes several controls for pre-dropout family and environmental characteristics including race dummies, family income in 1997 (the first year of the survey) ${ }^{2}$, a dummy for whether the respondent's mother gave birth while in her teens, a dummy for whether the respondent lived in an urban area at age 12, a dummy indicating the presence of gangs in the respondent's school in 1997, a dummy indicating the respondent lived in a two parent household at age 12, and dummies for region of residence at age 12. The third specification further adds academic achievement information in the form of AFQT scores and a dummy for whether the respondent earned high grades (A's and B's or better) in $8^{\text {th }}$ grade, as well as a dummy indicating whether the respondent earned low grades (mostly D's or worse) in $8^{\text {th }}$ grade. $^{3}$ The fourth specification further adds several pre-dropout behavioral characteristics including a delinquency index evaluated in 1997, an indicator for whether the respondent smoked marijuana before the age of 16 , and the number of times the respondent was suspended from school before the age of 16. Finally, the fifth specification is the same as the fourth specification but limits the sample to only dropouts and those who attended grade 12 before the age of 19 but no more.

The numbers in Table 3 correspond to only the coefficient on the indicator for the respondent being a dropout in each specification. The first outcome of interest is log wage rate in 2006, the results of which are shown in the top row of Table 3 . Those for whom no wage data was available (for 2006 or 2005), either because they were not interviewed or because they did not work over this period, were not included in the data used for these log wage specifications. Assuming the relevant wage rate for those who do

\footnotetext{
${ }^{2}$ As well as a dummy if the respondent was missing family income information.

${ }^{3}$ As well as a dummy if the respondent was missing grade information from $8^{\text {th }}$ grade.
} 
not report a wage rate is likely well below the median reported wage rate, and the fact that a somewhat higher fraction of high school dropouts than high school completers had missing wage data, the results shown in the top row of Table 3 likely understate the true wage inequality between high school dropouts and high school completers. As can be seen in specification (1) in Table 3, even when focusing on only those with positive reported wage data, dropouts earn about 17 percent less per hour than high school completers. However, controlling for more and more pre-dropout characteristics (moving from specification 1 to 4 ) decreases the magnitude of the coefficient on the dropout dummy by roughly 50 percent. When the sample is restricted in the fifth specification to dropouts and those that attended grade twelve but not higher, the coefficient on the dropout indicator becomes even a bit smaller in magnitude, to only about 40 percent of the original coefficient.

The coefficients shown in the second row of Table 3 tell a relatively similar story with respect to log annual earnings. Analogous to the wage specifications, those individuals who did not have valid earnings data (no earnings data in 2006 or 2005), or who reported earnings of zero were excluded. Moving across specifications we see that controlling for pre-dropout characteristics decreases the coefficient on the dropout indicator by almost a third, again showing that a sizeable fraction of the annual earnings gap between high school dropouts and high school completers is explained by differences in pre-dropout achievement and background characteristics. However, moving to specification (5), we see that further limiting the sample to only dropouts and individuals who attend no higher than grade twelve has very little effect on the magnitude of the coefficient on the dropout dummy (it actually increases the magnitude a small amount).

Again, these results might be somewhat misleading since those who report earnings of zero are not included, and dropouts make up a disproportionate fraction of this group. Therefore, the third row of Table 3 shows the results when earnings percentile (among all males) is used as the dependent variable, and thereby can include those individuals who report zero earnings in 2006, as they are simply measured as having earnings in the first percentile of the earnings distribution. As can be seen, the coefficients in the third row of Table 3 tell a similar story to as the previous outcomes. Namely, there is a sizeable earnings gap between high school dropouts and high school 
completers, but roughly a third of this gap can be explained by pre-dropout differences in the background, achievement, and behavioral characteristics used here.

The lower panel in Table 3 shows analogous results for the criminal activity variables which show a relatively similar story as those discussed above with respect to labor market outcomes. ${ }^{4}$ Namely, high school dropouts report committing more property crimes and drug sales and being arrested more often than high school completers.

However, successively controlling for background characteristics, academic achievement, and behavior, and limiting the sample of high school completers to only those who did not go on to college, continually lowers the magnitude of the coefficient controlling for achievement and family background characteristics, indicating that between one-third to one-half of the differential property crime participation and arrests between high school dropouts and high school completers in 2003 is explained by pre-dropout differences between these two groups.

In general, these results show that a significant fraction of the differences in early adulthood labor market and criminal outcomes between high school dropouts and high school completers can be accounted for by pre-dropout differences in a just a few background, academic achievement, and behavioral characteristics. However, a good deal remains unexplained by this limited set of covariates.

\section{III(b) - Accounting for the Reason Given for Dropping Out}

As discussed in the previous section, there are a variety of reasons individuals may choose to drop out and it will be informative to consider whether these reasons are correlated with future labor market and criminal outcomes. Table 4 shows the distribution of the reasons dropouts in the NLSY97 gave for dropping out. These reasons are divided into four general categories: (1) Dropped out to work or take care of family members, (2) Dropped out because respondent didn't like school, (3) Dropped out for behavioral reasons, (4) dropped out for "other passive" reasons.

\footnotetext{
${ }^{4}$ For the criminological outcomes, I use Poisson regressions since the number of criminal offenses and arrests are count variables and therefore better modeled as a Poisson process. Using Poisson regressions also allows me to control for variation in "exposure" times, or variation in the time between interviews between respondents, which is a feature of the NLSY interviewing procedure.
} 
As can be seen, the distribution of reasons given for dropping out is relatively diffuse, with no single reason accounting for more than $21 \%$ and the rest accounting for far less. Moreover, as I argued above, the reasons contained in the first category, "dropped out to work or take care of family," can generally be classified as pull reasons for dropping out, meaning the individual dropped out because he actively saw what he considered a better use of his time than further schooling and was thereby "pulled" away. On the other hand, the reasons making up categories 3 and 4, "behavioral" and "other passive," I would consider to be relatively passive reasons for dropping out on the part of the respondent, or in other words, rather than making an active decision to drop out these individuals were in a sense pushed out of school. Finally, I would argue that the reasons given for dropping out Category 2, "did not like school," are somewhere in between pulled and pushed notions regarding the activeness of the individual's decision making with respect to dropping out.

These reasons for dropping out were elicited in each year of the survey referring to why the student left school the most recent time. For the purposes of this analysis, the relevant dropout reason corresponds to the last time the student left school prior to the age of 19 for those who had not yet commenced twelfth grade. Note that these answers will be retrospective in the sense that they were elicited after the decision to drop out was made, but the gap between when the student dropped out and when he gave his reason for dropping out is less than a year for the respondents, since they are interviewed annually.

It should be noted that the NLSY97 respondents were only allowed to name one reason for dropping out. Clearly, for many individuals, the decision to drop out is the culmination of many factors. If all, or at least most of the reasons were of a similar category among those proposed above, for example "to work" and "to take care of family members", or "low grades" and "suspension," then this is not an issue. If on the other hand, the reasons for dropping out for many individuals' crossed categories, for example "to work" and "suspension," then these broad categories proposed above are less meaningful and therefore should not result in very significant differences across categories in terms of early adulthood outcomes.

To incorporate these reasons for dropping out into the outcomes analysis, I run regressions similar to equation (1), but instead of including a single indicator variable for 
whether or not the individual is a dropout, I include four separate indicator variables corresponding to the four general dropout categories defined in Table 4. Moreover, I use only the subsample of respondents who either dropped out before $12^{\text {th }}$ grade or attended grade 12 but no higher before the age of $19 .{ }^{5}$ Therefore, the coefficients on each of these indicator variables will reveal how individuals who dropped out for that reason lagged behind their otherwise observationally similar individuals who attended grade twelve by the age of 19 but no more. Once again, all of the family environment, academic achievement, and pre-dropout behavioral variables used previously are included in all regressions.

Table 5 shows the results of these regressions that incorporate the reason for dropping out dummy variables. ${ }^{6}$ Specifications (1) - (3) show the results for the labor market outcomes, while specifications (4) - (6) show the results for the crime outcomes. Looking first at log wage rates for those who reported valid wage rates (specification (1)), we can see that the coefficients on all of the dropout variables are negative, with the coefficients on the "dropped out for behavioral reason" and "dropped out for other passive reason" indicators both being significantly different from zero at the one percent level. However, the coefficients on the indicators for "dropped out because disliked school" and "dropped out to work or take care of family" are not statistically significant at any standard level of significance, and especially in the case of the coefficient on the latter variable, the magnitude of these coefficients are substantially smaller than those on the "dropped out for behavioral reasons" and "dropped out for other reasons" indicator variables. However, an F-test testing the equality of each of the dropout reason coefficients relative to the coefficient on the "Dropped out to work..." indicator is not statistically significant for any of the categories (p-values for F-test shown in brackets below standard errors).

The results with respect to log earnings for those with positive reported annual earnings in 2006 are reported in specification (2) in Table 5. In this case, the coefficients on the different dropout dummies reveal that those individuals who drop out because they

\footnotetext{
${ }^{5}$ Using the full sample of high school completers does not change the results qualitatively. Results available upon request.

${ }^{6}$ Coefficients on family environment, academic achievement, and pre-dropout behavior omitted for presentation reasons but available upon request.
} 
"disliked school," or for a "behavioral" and "other passive" reasons, all earn significantly less than otherwise observationally similar individuals who continue through to the twelfth grade. However, those who drop out to "work or take care of family members" again earn similar amounts in their early twenties as otherwise similar individuals who continue through to twelfth grade, with the difference not statistically significant at any standard level of significance. Moreover, an F-test testing the equality of each of the coefficients on the other dropout categories relative to the coefficient on the "Dropped out to work..." indicator variable can all be rejected at the one percent level (p-values shown in brackets below standard errors).

Finally, specification (3) reveals an almost identical picture when earnings percentile in 2006 is used as the dependent variable, allowing those with reported earnings of zero to be included in the sample. Again, as can be seen by terms in brackets, the coefficient on the "Dropped out to work..." indicator is significantly different than the coefficients on the other dropout variables at the $5 \%$ level or better.

In words, these results reveal that while those individuals who drop out for "behavioral" and "other passive" reasons, and to some extent those who "dislike school," earn substantially less in their early twenties than otherwise observationally similar individuals who continued through to twelfth grade, those who dropped out to work or take care of family members do not appear to earn much less than their observationally similar counterparts who continued through to twelfth grade.

Specifications (4) - (6) tell a mostly similar story as above when it comes to crime outcomes. In particular, those individuals who drop out for "behavioral" and "other passive" reasons commit significantly more property crimes and drug sales in 2003, and are arrested more frequently in 2003, than their observationally similar counterparts who continue through up to twelfth grade. Those individuals who drop out because they "dislike school" also appear to commit more crimes later in life and are arrested more often than their observationally similar counterparts who continue through twelfth grade, but to a somewhat lesser extent than the two categories of dropouts mentioned above. Most notably however, the coefficients corresponding to the indicator for "dropped out to work or take care of family" are relatively smaller in magnitude for the three crime categories (with the coefficient with respect to property crimes actually being negative), 
and generally statistically different from the coefficients on the other dropout category indicators (again, terms in brackets below standard errors show p-value on F-test for equality between these coefficients and the coefficient on the "Dropped out to work..." indicator).

In words, these coefficients suggest that those who drop out of school to "work or take care of family members" appear to commit roughly the same number of property crimes, and are only slightly more prone to selling drugs or being arrested in their early twenties than otherwise similar individuals who continue through to twelfth grade. However, those who drop out because they "dislike school," and especially those who drop out for "behavioral" or "other passive" reasons, appear to be engaged in substantially more criminal activity in their early twenties than either otherwise similar individuals who continue through to twelfth grade, or those who dropped out to "work or take care of family."

\section{III(c) - Robustness Checks Using Propensity Score Matching}

In general, the results shown in Table 5 show that after controlling for a variety of key individual characteristics while young that may affect both later labor market and criminal outcomes, individuals who drop out to "work or take care of family members" have labor market and criminal outcomes generally more comparable to those individuals who continue through twelfth grade than to those who drop out because they "disliked school" or because of "behavioral" and "other passive" reasons.

One concern however, is that the regression specifications are imposing too much structure on the data. In particular, as shown in Table 2, the high school dropouts have very different pre-dropout characteristics than the high school completers and therefore the linearity assumptions implicit in the OLS regression specifications may be misleading due to weakly overlapping support of the regressors. This section examines the robustness of the results shown in Table 5 by using propensity score matching.

For each labor market and criminal outcome I separately estimate the effects of four different treatments (dropped out of school to work or take care of family, dropped out because disliked school, dropped out for behavioral reasons, dropped out for other passive reasons) relative to the control group of individuals who attended twelve years of 
schooling but no more by the age of 19. For each treatment, I first estimated the propensity score for receiving the treatment using a probit regression based on the observable characteristics used in the previous regression specifications discussed above. I then used a Gaussian kernel matching estimator to estimate the Average-treatment-onthe-treated (ATT). ${ }^{7}$ Standard errors were obtained via bootstrapping.

Essentially, this method compares the outcomes for all those individuals who got a specific "treatment," for example dropped out to work or take care of family, to the outcomes for a sample of high school completers weighted to have similar characteristics to the treated. Intuitively, this method will upweight those high school completers who have similar observable characteristics a given dropout group (e.g., those who dropped out to work or take care of family, or those who dropped out for behavioral reasons) and downweights those high school completers who have very different observable characteristics to this group.

Table 6 presents the results from these propensity score matching estimates. Looking first at the results with respect to reported wage in 2006 (the first column of numbers), we again see that those who drop out in order to "work or take care of family" do no worse in terms of future wages than otherwise similar individuals who continue through up to twelfth grade. However, those who drop out because they "dislike school" do significantly worse than otherwise similar individuals who continue through up to twelfth grade. Finally, while the point estimate for those who drop out for "behavioral" reasons is negative and quite large, it is very imprecisely estimated. Similarly, the point estimate for those who drop out for "other passive" reasons is also not statistically significant.

However, the results with respect to earnings in 2006 for those with positive reported earnings, and for earnings percentile in 2006 for those with positive and zero reported earnings, are very qualitatively similar to those coming from the regressions in Table 5. Namely, while those who drop out to "work or take care of family members" have marginally lower earnings than otherwise similar individuals who continue through twelfth grade, this earnings gap is not statistically significant. However, those who drop

\footnotetext{
${ }^{7}$ I used the attk command in Stata, specifying estimation only on a common support. See Abadie et al. (2004) for more details.
} 
out because they "dislike school," and those who drop out for "behavioral" and "other passive" reasons, again appear to earn substantially and significantly less in their early twenties than observationally similar high school completers.

With respect to criminal outcomes, the matching estimator results are somewhat imprecisely estimated, but again generally quite comparable to the regression results shown in Table 5. Namely, those who drop out to "work or take care of family members" do not appear to commit significantly more crimes or be arrested significantly more often later in life than otherwise similar high school completers. However, there is some evidence that those who drop out because they "dislike school" sell more drugs later in life than otherwise similar high school completers, while those who drop out for "behavioral" reasons appear to commit more crimes and are arrested significantly more often later in life than otherwise similar high school completers. In general, the matching results with respect to criminal outcomes show that of the four dropout groups, only those who said they dropped out to work or take care of family did not have significantly different outcomes than high school completers in any of the three criminal categories.

In summary, the propensity score matching estimates seem to by and large corroborate the regression results discussed in the previous sub-section.

\section{IV - Discussion of the Results}

The key findings in the previous analysis suggest that there are important heterogeneities with respect to high school dropouts. Namely, while most high school dropouts do substantially worse in their early twenties in terms of labor market and criminal outcomes, a sizeable subset of dropouts, namely those who claim to drop out in order to work or take care of family (i.e., arguably felt pulled away from school), do not appear to do appreciably worse than high school completers with similar observable backgrounds. This also suggests that if one believes the earlier cited literature that uses plausibly exogenous sources of variation in schooling to find large causal effects of a few months more schooling on future labor market and criminal outcomes for those on the margin of dropping out, then these effects must come almost exclusively from those who otherwise would have left school for arguably more passive reasons, such as expulsion, 
family moves, health problems, drug and alcohol problems, or simply because they did not like school (i.e., felt pushed out).

The question remains why do those dropouts who feel pulled out of school by work or take care of family fare roughly the same as their otherwise similar high school completing peers, while those who dropout because they feel more pushed out do so much worse? After all, members of all of these dropout groups are similarly missing out on the human capital that is being developed through this further schooling that their high school completing counterparts are obtaining. Why does this deficiency appear to have such larger longer term effects on those who felt pushed out of school relative to those who felt pulled out of school in order to work or take care of family?

One explanation may be that all of these dropout groups are similarly hurt by dropping out of school, but the groups are composed of very different types of individuals and we should actually have expected those who say they dropped out to work or take care of family members to do better than their counterparts who stayed in school. This seems unlikely though as it does not appear that those who drop out to work or take care of family have pre-dropout characteristics that pre-dispose them to do better later in life than the other dropout groups.

In particular, Table 7 shows how the different dropout groups differ over a number of different characteristics. The terms in brackets show the p-values for the significance of the difference between each given characteristic for each dropout group and the analog for that characteristic for those who dropped out to work or take care of family. The only really notable differences across dropout groups is that those who dropped out to work or take care of family are less likely to be black, but are more likely to be Hispanic, and actually come from families with lower income in 1997. However, there are generally no statistical differences between those who dropped out to work or take care of family and members of the other dropout groups with respect to other household environment characteristics, pre-dropout academic achievement, or even really behavioral characteristics (other than compared to those who dropped out due to behavioral problems).

Certainly one way in which dropouts may be heterogeneous is in their motivation to succeed later in life, which obviously is quite hard to measure. Moreover, it is certainly 
possible, indeed probable, that those who felt pulled from school either by work or family obligations, are on average more motivated than those dropouts who felt pushed from school. One way such motivation may manifest itself is through how dropouts use their time just after dropping out. In particular, to what extent do they apply their time to other human capital enhancing activities versus simply remain idle.

One way to look at this issue is to see how much members of the different dropout categories worked in the months just after dropping out. The Work History Files of the NLSY97 allow us to observe such data. Before describing these results, it should be noted that there is likely a good deal of measurement error with respect to how I measure these hours worked just after dropping out for a couple of reasons. First, there is substantial missing data. To handle this, I consider the average hours worked per week in the three months just subsequent to dropping out. This average is just taken with respect to weeks for which there is data. Second, and possibly more problematic, it is difficult to calculate the exact time an individual drops out, as many dropouts leave and return to school several times before the age of 19. For purposes of this analysis, I calculated the time an individual dropped out as the last time the individual was enrolled in high school for two consecutive months followed by three months of not being enrolled before the age of 19 (for those who had not yet attended grade twelve).

As can be seen in the top row of Table 8, those who claimed to drop out in order to work or take care of family actually did work significantly more hours in the months just after dropping out than those dropouts in the other dropout categories---on the order of over fifty percent more hours each week. Moreover, those who claimed they dropped out in order to work or take care of family were roughly half as likely to not work at all in the first three months after dropping out as members of the other dropout groups.

These results show that those individuals who felt pulled out of school in order to do something else with their time appear to actually have followed through with these plans, and were far less likely to simply be idle (i.e., not in school, not working) in the months immediately following dropping out than those dropouts who arguably felt pushed out of school. In other words, it appears that those who felt pulled out of school often substituted work time for the time they used to be in school. Such work experience is also likely a human capital building activity, not only through learning the hard skills 
of a given trade, but maybe more importantly through teaching and rewarding many of the "soft" skills also taught and rewarded in school such as punctuality, responsibility, and respect for authority and rules. Therefore, maybe it should not be that surprising that these individuals do not appear to have suffered too much over the longer-term much for making this substitution.

On the other hand, for those who felt pushed out of school, the relatively few hours of work in the months after dropping out, and especially the high fraction of these individuals who did not work at all the three months subsequent to dropping out of school, reveals that many of these individuals simply became idle after dropping out--certainly not a productive way to build human capital. Indeed, such idle time may actually deteriorate human capital. For example, there is evidence that such idle time may lead individuals to become more involved in crime which may demand less respect for authority and rules (Jacob and Lefgren 2003).

In the end, these results are consistent with the notion that much of the previously cited longer-term benefits to keeping youth in school an additional few months is not necessarily that this increases their academic knowledge, but rather that it helps many them continue to build on their softer skills such as punctuality, responsibility, and respect for authority and rules, rather than becoming idle, and it is maintaining these softer skills that is helpful for success later in life.

\section{V - Summary and Conclusion}

This paper re-examines the longer term outcomes for high school dropouts and highlights some important heterogeneities with respect to dropouts. In particular, dropouts leave school for a variety of reasons and these reasons have strong correlations with future labor market and criminal outcomes. Most notably, those who say dropped out for push reasons, such as they didn't like school, had behavioral issues such as being suspended or a drug problem, or other "passive" reasons like moving, do appear to fare much worse than those who continue through to the twelfth grade even after controlling for a variety of pre-dropout environmental, academic achievement, and behavioral characteristics. However, those who say they dropped out due to pull reasons, such as to work or take care of family members, actually appear to do roughly the same with respect 
to future earnings and labor market outcomes, as well as future criminal activity, to those who continue through to the twelfth grade with similar pre-dropout characteristics. This finding suggests that, at least for this latter group of dropouts, leaving school does not appear to have very large negative consequences on future life outcomes.

Arguably, even though all of these dropouts are foregoing the human capital building that goes along with finishing high school, those who say they drop out to work or take care of family are still obtaining many of the softer skill human capital benefits of further schooling, such as punctuality, responsibility, and respect for authority and rules, through joining the labor force directly upon dropping out. This may partly explain why there do not appear to be substantial long-term consequences to dropping out for this group.

On the other hand, it appears that many of those who drop out for push reasons simply become idle in the months following dropping out. Therefore, not only are they missing out on the academic learning that their high school completing peers engage in while still at school, but also lose out on the development and maintenance of the softer skills that both their high school completing peers, as well as their fellow dropouts who move directly into the labor market after dropping out, continue to develop.

In summary, these results suggest that keeping all of those on the verge of dropping out in the classroom may not necessarily be the key to helping their longer-term outcomes, especially if such students create negative externalities to others. Rather, it is making sure that those on the verge of dropping out continue to use their time in a productive manner and develop and maintain their soft skills that may be key. 


\section{Data Appendix}

Construction of key variables:

The criteria for being labeled a dropout for the purposes of this paper were threefold. First, the highest grade the individual reported attending by the age of 19 was grade 11 or below. Second, the individual did not say that the reason he left school was because he graduated or received degree. Finally, the respondent did not report receiving a high school degree by age 19 . Note that this means there are individuals who dropped out of high school, in the sense that they did not graduate, in the group of high school completers.

The reason for dropping out variable was determined by the question that asked "what was the main reason you left at this time?" referring to when they left a given school. The school determined to be the "dropout" school was the last non-college school the individual attended prior to the age of 19.

Average hours worked per week after dropping out was determined as follows. First, the date at which an individual dropped out was calculated by determining the last month in which the student was enrolled in that month and the previous month, but not enrolled or on vacation for the next four months. After calculating the date of dropping out, calculating the average hours worked per week in the three months following dropping out was straightforward from the event history data. 


\section{VI - References}

Abadie, A., D. Drukker, J. Leber Herr, and Guido Imbens. (2004). "Implementing Matching Estimators for Average Treatment Effects in STATA.” The Stata Journal 4(3): 290-311.

Alexander, Karl L., Doris R. Entwisle, and Carrie S. Horsey. (1997). "From First Grade Forward: Early Foundations of High School Dropout." Sociology of Education 70: 87107.

Anderson, D. Mark. (2010). "In School and Out of Trouble? Compulsory Schooling and Juvenile Crime." Working Paper---University of Washington Department of Economics.

Angrist, Joshua and Alan Krueger (1991) "Does Compulsory School Attendance Affect Schooling and Earnings?” Quarterly Journal of Economics 106(4): 979 - 1014.

Chandra, Amitabh. (2000). "Labor-Market Dropouts and the Racial Wage Gap: 19401990." American Economic Review (AEA Papers and Proceedings) 90(2): 333-338.

Chevalier, Arnaud, Colm Harmon, Ian Walker, Yu Zhu. (2004). "Does Education Raise Productivity, or Just Reflect It?” The Economic Journal 114: F499-F517.

Chuang, Hwei-Lin. (1997). "High School Youths' Dropout and Re-enrollment Behavior." Economics of Education Review 16: 171-186.

Eckstein, Zvi and Kenneth I. Wolpin. (1999). "Why Youths Drop Out of High School: The Impact of Preferences, Opportunities, and Abilities." Econometrica 67(6): 12951339.

Entwistle, Doris R., Karl L. Alexander, and Linda Steffel Olso. (2004). "Temporary as Compared to Permanent High School Dropout." Social Forces 82: 1181-1205.

Fine, Michelle. (1986). "Why Urban Adolescents Drop Into and Out of High School." Teachers College Record 87: 393-409.

Harmon, Colm and Ian Walker. (1995). "Estimates of the Economic Return to Schooling for the United Kingdom," American Economic Review, December 1995: 1278-86.

Heckman, James J., Hidehiko Ichimura, and Petra Todd. (1998). "Matching as an Econometric Evaluation Estimator.” Review of Economic Studies 65(2).

Jacob, Brian, and Lars Lefgren. (2003). “Are Idle Hands the Devil's Workshop? Incapacitation, Concentration, and Juvenile Crime." American Economic Review 93(5): $1560-1577$. 
Jarjoura, G. Roger. (1993). "Does Dropping out of School Enhance Delinquent Involvement? Results from a Large-scale National Probability Sample." Criminology 31: $149-172$.

Jordan, Will J., Julia Lara, and James M. McPartland. (1996). "Exploring the Causes of Early Dropout Among Race-Ethnic and Gender Groups." Youth \& Society 28(1): 62-94.

McNeal, Ralph. (1997). “Are Students Being Pulled Out of High School? The Effect of Adolescent Employment on Dropping Out.” Sociology of Education 70: 206-220.

Mihalic, Sharon Wofford, Delbert Elliot. (1997). "Short and Long-term Consequences of Adolescent Work." Youth \& Society 28: 464-498.

Neal, Derek and William R. Johnson. (1996). "The Role of Pre-Market Factors in BlackWhite Wage Differences." Journal of Political Economy 104(5): 869-95.

Lochner, Lance and Enrico Moretti. (2004). "The Effect of Education on Crime: Evidence from Prison Inmates, Arrests, and Self-Reports." American Economic Review 94(1): 155 - 89.

Oreopolous, Phillip. (2003). "Do Dropouts Drop Out Too Soon? Wealth, Health, and Happiness from Compulsory Schooling.” NBER Working Paper 10155.

-----. (2008). "Should We Raise the Minimum School Leaving Age to Help Disadvantaged Youth? Evidence from Recent Changes to Compulsory Schooling in the United States." in An Economic Framework for Understanding and Assisting Disadvantaged Youth ed. Jonathan Gruber, Cambridge: NBER.

Rumberger, Russel W. (1987). "High School Dropouts: A Review of Issues and Evidence." Review of Educational Research 57(2): 101-121.

Rumberger, Russell W. and Stephen P. Lamb. (2003). “The Early Employment and Further Education Experiences of High School Dropouts: A Comparative Study of the United States and Australia." Economics of Education Review 22: 353-366.

Sweeten, Gary, Shawn Bushway, Ray Paternoster. (2009). "Does Dropping out of School Mean Dropping into Delinquency?” Criminology 47(1): 47-91.

Thornberry, Terence P., Melanie Moore, and R.L. Christenson. (1985). “The Effect of Dropping Out of High School on Subsequent Criminal Behavior.” Criminology 23(1): 3 18. 
Table 1 - Mean Outcome Differences Between High School Dropouts and High School Completers

\begin{tabular}{|c|c|c|c|c|}
\hline Outcome & $\begin{array}{c}\text { Less than } 12 \text { yrs } \\
\text { of education by age } 19 \\
\text { ("HS Dropouts") }\end{array}$ & $\begin{array}{c}12 \text { yrs or more } \\
\text { of education by age } 19 \\
\text { ("HS Completers") }\end{array}$ & Difference & obs \\
\hline Hourly Wage (2006) & $\begin{array}{c}8.96 \\
(0.379)\end{array}$ & $\begin{array}{c}11.60 \\
(0.247)\end{array}$ & $\begin{array}{c}-2.64 \\
(0.45)^{\star \star \star}\end{array}$ & 3447 \\
\hline Individual Earnings (2006) & $\begin{array}{c}13,740.61 \\
(621.89)\end{array}$ & $\begin{array}{c}20,613.74 \\
(353.6)\end{array}$ & $\begin{array}{l}-6,873.13 \\
(715.39)^{\star \star \star}\end{array}$ & 3072 \\
\hline Number of Arrests (2003) & $\begin{array}{l}0.44 \\
(0.097)\end{array}$ & $\begin{array}{c}0.10 \\
(0.022)\end{array}$ & $\begin{array}{c}0.34 \\
(0.10)^{\star \star \star}\end{array}$ & 3063 \\
\hline Number of Times Sold Drugs (2003) & $\begin{array}{c}1.78 \\
(0.249)\end{array}$ & $\begin{array}{c}0.78 \\
(0.080)\end{array}$ & $\begin{array}{c}1.00 \\
(0.26)^{\star \star \star}\end{array}$ & 3053 \\
\hline Number of Property Crimes (2003) & $\begin{array}{c}0.39 \\
(0.144)\end{array}$ & $\begin{array}{c}0.15 \\
(0.026)\end{array}$ & $\begin{array}{c}0.24 \\
(0.15)\end{array}$ & 2995 \\
\hline
\end{tabular}

Note: Sample consists of males who had valid AFQT scores and valid information on highest grade attended prior to the age of 19. Standard errors in parentheses. 
Table 2 - Mean Background Characteristics For High School Dropouts and High School Completers

\begin{tabular}{|c|c|c|c|}
\hline Characteristic & $\begin{array}{c}\text { Less than } 12 \text { yrs } \\
\text { of education by age } 19 \\
\text { ("HS Dropouts") }\end{array}$ & $\begin{array}{c}12 \text { yrs or more } \\
\text { of education by age } 19 \\
\text { ("HS Completers") }\end{array}$ & $\begin{array}{c}12 \text { yrs only } \\
\text { of education by age } 19 \\
\text { ("HS Only") }\end{array}$ \\
\hline Black & $\begin{array}{c}0.36 \\
(0.02)\end{array}$ & $\begin{array}{c}0.23 \\
(0.01)\end{array}$ & $\begin{array}{c}0.27 \\
(0.01)\end{array}$ \\
\hline Hispanic & $\begin{array}{c}0.29 \\
(0.02)\end{array}$ & $\begin{array}{c}0.17 \\
(0.01)\end{array}$ & $\begin{array}{c}0.21 \\
(0.01)\end{array}$ \\
\hline Household Income (1997) & $\begin{array}{l}\$ 27,946 \\
(1,2092)\end{array}$ & $\begin{array}{l}\$ 53,973 \\
(971)\end{array}$ & $\begin{array}{l}\$ 40,593 \\
(962)\end{array}$ \\
\hline Lived with two parents at age 12 & $\begin{array}{c}0.26 \\
(0.02)\end{array}$ & $\begin{array}{c}0.53 \\
(0.01)\end{array}$ & $\begin{array}{c}0.42 \\
(0.01)\end{array}$ \\
\hline Lived in Urban area at age 12 & $\begin{array}{c}0.60 \\
(0.02)\end{array}$ & $\begin{array}{l}0.60 \\
(0.01)\end{array}$ & $\begin{array}{l}0.55 \\
(0.01)\end{array}$ \\
\hline Mother gave birth as teenager & $\begin{array}{c}0.18 \\
(0.02)\end{array}$ & $\begin{array}{c}0.09 \\
(0.01)\end{array}$ & $\begin{array}{c}0.13 \\
(0.01)\end{array}$ \\
\hline Gangs in school (1997) & $\begin{array}{c}0.55 \\
(0.02)\end{array}$ & $\begin{array}{c}0.43 \\
(0.01)\end{array}$ & $\begin{array}{l}0.47 \\
(0.01)\end{array}$ \\
\hline AFQT score & $\begin{array}{l}21.57 \\
(0.78)\end{array}$ & $\begin{array}{l}50.52 \\
(0.55)\end{array}$ & $\begin{array}{l}29.84 \\
(0.68)\end{array}$ \\
\hline $\begin{array}{l}\text { High Grades 8th Grade } \\
\text { (A's and B's or better) }\end{array}$ & $\begin{array}{c}0.10 \\
(0.01)\end{array}$ & $\begin{array}{c}0.36 \\
(0.01)\end{array}$ & $\begin{array}{c}0.20 \\
(0.01)\end{array}$ \\
\hline $\begin{array}{l}\text { Low Grades 8th Grade } \\
\text { (Mostly D's or lower) }\end{array}$ & $\begin{array}{c}0.32 \\
(0.02)\end{array}$ & $\begin{array}{c}0.10 \\
(0.01)\end{array}$ & $\begin{array}{c}0.16 \\
(0.01)\end{array}$ \\
\hline Delinquency Index & $\begin{array}{c}2.43 \\
(0.09)\end{array}$ & $\begin{array}{c}1.50 \\
(0.03)\end{array}$ & $\begin{array}{c}1.76 \\
(0.05)\end{array}$ \\
\hline Smoked marijuana $<16$ yrs old & $\begin{array}{c}0.30 \\
(0.02)\end{array}$ & $\begin{array}{c}0.17 \\
(0.01)\end{array}$ & $\begin{array}{c}0.21 \\
(0.01)\end{array}$ \\
\hline Days of suspension $<16$ yrs old & $\begin{array}{l}19.75 \\
(1.58)\end{array}$ & $\begin{array}{c}4.06 \\
(0.27)\end{array}$ & $\begin{array}{c}7.28 \\
(0.52)\end{array}$ \\
\hline
\end{tabular}

Note: Sample consists of males who had valid AFQT scores and valid information on highest grade attended prior to the age of 19. Standard errors in parentheses. 
Table 3 - Regression Results: Labor Market Outcomes

\begin{tabular}{|c|c|c|c|c|c|}
\hline \multirow[b]{3}{*}{ Outcome Variable } & \multicolumn{5}{|c|}{ Coefficient on Dropout Dummy by specification } \\
\hline & $\begin{array}{c}\text { birth year } \\
\text { dummies only }\end{array}$ & $\begin{array}{l}\text { + Controls for race, } \\
\text { family characteristics, } \\
\text { and environment }\end{array}$ & $\begin{array}{l}\text { + test scores } \\
\text { and grades }\end{array}$ & $\begin{array}{c}\text { + behavioral } \\
\text { measures }\end{array}$ & $\begin{array}{l}\text { high school } \\
\text { only sample }\end{array}$ \\
\hline & $(1)$ & $(2)$ & (3) & $(4)$ & (5) \\
\hline \multicolumn{6}{|l|}{ Labor Outcomes (OLS) } \\
\hline \multirow{2}{*}{ (i) log wage } & -0.169 & -0.111 & -0.090 & -0.084 & -0.072 \\
\hline & $(0.026)^{\star \star \star}$ & $(0.027)^{\star \star \star}$ & $(0.028)^{\star \star \star}$ & $(0.029)^{\star \star \star}$ & $(0.027)^{\star \star \star}$ \\
\hline \multirow[t]{2}{*}{ (ii) log earnings } & -1.490 & -1.257 & -1.060 & -1.019 & -1.105 \\
\hline & $(0.150)^{\star \star *}$ & $(0.156)^{\star \star \star}$ & $(0.167)^{\star \star \star}$ & $(0.170)^{\star \star \star}$ & $(0.173)^{\star \star \star}$ \\
\hline \multirow[t]{2}{*}{ (iii) earnings percentile } & -14.206 & -11.732 & -10.183 & -10.344 & -10.748 \\
\hline & $(1.303)^{\star \star \star}$ & $(1.350)^{\star \star \star}$ & $(1.437)^{\star \star \star}$ & $(1.464)^{\star \star \star}$ & $(1.414)^{\star \star \star}$ \\
\hline \multicolumn{6}{|c|}{ Crime Outcomes (Poisson) } \\
\hline \multirow[t]{2}{*}{ (i) property crimes } & 0.931 & 0.852 & 0.806 & 0.638 & 0.408 \\
\hline & $(0.086)^{\star \star \star}$ & $(0.093)^{\star \star \star}$ & $(0.102)^{\star \star \star}$ & $(0.103)^{\star \star \star}$ & $(0.099)^{\star \star \star}$ \\
\hline \multirow[t]{2}{*}{ (ii) drug sales } & 0.810 & 0.781 & 0.955 & 0.752 & 0.481 \\
\hline & $(0.038)^{\star \star \star}$ & $(0.042)^{\star \star \star}$ & $(0.045)^{\star \star \star}$ & $(0.045)^{\star \star \star}$ & $(0.045)^{\star \star \star}$ \\
\hline \multirow[t]{2}{*}{ (iii) arrests } & 1.516 & 1.379 & 0.952 & 0.831 & 0.906 \\
\hline & $(0.090)^{\star \star \star}$ & $(0.099)^{\star * \star}$ & $(0.108)^{\star \star \star}$ & $(0.108)^{\star \star \star}$ & $(0.102)^{\star \star \star}$ \\
\hline
\end{tabular}

Note: Sample for all specifications consists of males who had valid AFQT scores, had valid information on highest grade attended prior to the age of 19 , and who attended no higher than grade 12 prior to the age of 21 . Wage/Earnings specifications include only those who reported positive wages/earnings. Earnings Percentile specification also includes those with reported earnings of zero in the previous year.

Regressors in Specification (2) also include race dummies, household income in 1997, dummy for living with two parents at age 12, dummy for living in urban area at age 12, dummy for mother giving birth as a teenager, dummy for reporting gangs in school at age 12. Regressors in Specification (3) include all of those in Specification (2) as well as AFQT score, AFQT score squared, a dummy for high grades in 8th grade (A's and B's or better), a dummy for low grades in 8th grade (Mostly D's or lower), and a dummy for missing 8th grade grade information. Regressors in specification (4) include all of those in (3) as well as a delinquency index from 1997, a dummy for smoking marijuana before age 16, and number of days of suspension before age 16. Regressors in Specification (5) are identical to Specification (4). Standard errors in parentheses. * significant at 10\%; ** significant at $5 \%$; ${ }^{* \star}$ significant at $1 \%$. 
Table 4 - Distribution of Reasons Given for Dropping out of School Before Grade 12

\begin{tabular}{|c|c|c|c|}
\hline Categories & Reasons making up each category & Number & Fraction \\
\hline (1) To Work or Take & Offered Job & 57 & 0.23 \\
\hline \multirow[t]{6}{*}{ Care of Family } & Entered Military & 1 & 0.00 \\
\hline & Got Married & 1 & 0.00 \\
\hline & Child Care Responsibilities & 6 & 0.02 \\
\hline & Home Responsibilities & 18 & 0.07 \\
\hline & Became a father & 4 & 0.02 \\
\hline & subtotal & 87 & 0.13 \\
\hline \multirow[t]{4}{*}{ (2) Disliked School } & Did not like school & 147 & 0.60 \\
\hline & Didn't get along with other students & 21 & 0.09 \\
\hline & Home school & 3 & 0.01 \\
\hline & subtotal & 171 & 0.25 \\
\hline \multirow[t]{6}{*}{ (3) Behavioral } & Expelled & 65 & 0.26 \\
\hline & Suspended & 21 & 0.09 \\
\hline & Poor grades & 59 & 0.24 \\
\hline & Incarceration/legal problems & 19 & 0.08 \\
\hline & Had a problem with drugs or alcohol & 3 & 0.01 \\
\hline & subtotal & 167 & 0.25 \\
\hline \multirow[t]{12}{*}{ (4) Other "Passive" } & School too dangerous & 14 & 0.06 \\
\hline & Financial difficulties, couldn't afford to go & 17 & 0.07 \\
\hline & Moved away from school & 75 & 0.30 \\
\hline & My friends dropped out of school & 1 & 0.00 \\
\hline & Had a health problem & 11 & 0.04 \\
\hline & District changed/school closed/new school opened & 8 & 0.03 \\
\hline & Transportation problems/too far away & 15 & 0.06 \\
\hline & Not enough credits to graduate & 9 & 0.04 \\
\hline & Had to transfer to another school & 14 & 0.06 \\
\hline & Other (unspecified or uncodable) & 83 & 0.34 \\
\hline & subtotal & 247 & 0.37 \\
\hline & total & 672 & 1.00 \\
\hline
\end{tabular}


Table 5 - Regression Results: Controlling for Reason for Dropping Out

\begin{tabular}{|c|c|c|c|c|c|c|}
\hline \multirow[b]{2}{*}{ Control Variable } & \multicolumn{6}{|c|}{ Outcome } \\
\hline & $\begin{array}{l}\text { Log Individual } \\
\text { Wage (2006) } \\
\text { (1) - OLS }\end{array}$ & $\begin{array}{c}\text { Log Individual } \\
\text { Earnings (2006) } \\
(2) \text { - OLS }\end{array}$ & $\begin{array}{l}\text { Individual Earn. } \\
\text { Percentile (2006) } \\
\text { (3) - OLS }\end{array}$ & $\begin{array}{l}\text { Num. of Prop. } \\
\text { Crimes (2003) } \\
\text { (4) - Poisson }\end{array}$ & $\begin{array}{l}\text { Num. of Drug } \\
\text { Sales (2003) } \\
\text { (5) - Poisson }\end{array}$ & $\begin{array}{c}\text { Num. of Arrests } \\
(2003) \\
(6)-\text { Poisson }\end{array}$ \\
\hline $\begin{array}{l}\text { Dropped out to work or take } \\
\text { care of family }\end{array}$ & $\begin{array}{l}-0.034 \\
(0.062)\end{array}$ & $\begin{array}{c}0.051 \\
(0.119)\end{array}$ & $\begin{array}{l}-3.483 \\
(3.211)\end{array}$ & $\begin{array}{l}-0.211 \\
(0.269)\end{array}$ & $\begin{array}{l}0.263 \\
(0.105)^{\star \star}\end{array}$ & $\begin{array}{c}0.508 \\
(0.225)^{\star \star}\end{array}$ \\
\hline $\begin{array}{l}\text { Dropped out because } \\
\text { disliked school }\end{array}$ & $\begin{array}{c}-0.057 \\
(0.046) \\
{[0.75]}\end{array}$ & $\begin{array}{c}-0.323 \\
(0.091)^{\star \star \star} \\
{[0.009]}\end{array}$ & $\begin{array}{c}-11.756 \\
(2.401)^{\star \star \star} \\
{[0.030]}\end{array}$ & $\begin{array}{c}0.425 \\
(0.160)^{\star \star \star} \\
{[0.032]}\end{array}$ & $\begin{array}{c}0.650 \\
(0.066)^{\star \star \star} \\
{[0.001]}\end{array}$ & $\begin{array}{c}0.512 \\
(0.179)^{\star \star \star} \\
{[0.987]}\end{array}$ \\
\hline Dropped out for "behavioral" reason & $\begin{array}{c}-0.106 \\
(0.047)^{\star *} \\
{[0.32]}\end{array}$ & $\begin{array}{c}-0.464 \\
(0.093)^{\star \star \star} \\
{[0.000]}\end{array}$ & $\begin{array}{c}-13.540 \\
(2.447)^{\star \star \star} \\
{[0.009]}\end{array}$ & $\begin{array}{c}0.689 \\
(0.139)^{\star \star \star} \\
{[0.002]}\end{array}$ & $\begin{array}{c}0.673 \\
(0.066)^{\star \star \star} \\
{[0.000]}\end{array}$ & $\begin{array}{c}0.834 \\
(0.150)^{\star \star \star} \\
{[0.183]}\end{array}$ \\
\hline Dropped out for other "passive" reason & $\begin{array}{c}-0.076 \\
(0.039)^{*} \\
{[0.54]}\end{array}$ & $\begin{array}{c}-0.317 \\
(0.076)^{\star \star \star} \\
{[0.006]}\end{array}$ & $\begin{array}{c}-10.858 \\
(1.999)^{\star \star \star} \\
{[0.040]}\end{array}$ & $\begin{array}{c}0.338 \\
(0.140)^{\star \star} \\
{[0.057]}\end{array}$ & $\begin{array}{c}0.245 \\
(0.067)^{\star \star \star} \\
{[0.880]}\end{array}$ & $\begin{array}{c}1.248 \\
(0.122)^{\star \star \star} \\
{[0.001]}\end{array}$ \\
\hline $\begin{array}{l}\text { Observations } \\
\text { Note: Sample for all specifications consi }\end{array}$ & $\frac{1738}{\text { ists of males n }}$ & $\frac{1705}{\text { ad valid AFQ7 }}$ & $\frac{1993}{\text { res, had valid i }}$ & $\frac{1893}{\text { nation on hig }}$ & $\frac{1948}{\text { grade atten }}$ & $\begin{array}{l}1958 \\
\text { d prior to the } \\
\text { reported }\end{array}$ \\
\hline $\begin{array}{l}\text { In all specifications, other regressor } \\
\text { two parents at age } 12 \text {, dummy for living } \\
\text { school at age } 12, \text { AFQT score, AFQT so } \\
\text { 8th grade (Mostly D's or lower), and a du } \\
\text { marijuana before age } 16 \text {, and number o } \\
5 \% \text {; } * \star \text { significant at } 1 \% \text {. Terms in brack }\end{array}$ & $\begin{array}{l}\text { rs include include } \\
\text { in urban area at } \\
\text { core squared, a d } \\
\text { ummy for missing } \\
\text { f days of suspens } \\
\text { kets show p-value }\end{array}$ & $\begin{array}{l}\text { birth year dummie } \\
\text { age } 12 \text {, dummy for } \\
\text { dummy for high gra } \\
\text { g } 8 \text { th grade grade ir } \\
\text { ision before age } 16 \text {. } \\
\text { le of test for equalit }\end{array}$ & $\begin{array}{l}\text { es, race dummies, ho } \\
\text { r mother giving birth } \\
\text { ades in 8th grade ( } A \text { 's } \\
\text { information, a deling } \\
\text { Standard errors in } \\
\text { ty between that coeff }\end{array}$ & $\begin{array}{l}\text { lousehold income } \\
\text { as a teenager, } \\
\text { 's and B's or bette } \\
\text { quency index fron }\end{array}$ & $\begin{array}{l}\text { nmy for rep } \\
\text {, a dummy }\end{array}$ & $\begin{array}{l}\text { y for living with } \\
\text { ting gangs in } \\
r \text { low grades in } \\
\text { ny for smoking } \\
\% \text {; } * \text { significant at } \\
\text { on "dropped out }\end{array}$ \\
\hline
\end{tabular}


Table 6 - Estimates of Average-Treatment-on-the-Treated Using Propensity Score Matching

\begin{tabular}{|c|c|c|c|c|c|c|}
\hline \multirow[b]{2}{*}{ Control Variable } & \multicolumn{6}{|c|}{ Outcome } \\
\hline & $\begin{array}{c}\text { Individual } \\
\text { Wage (2006) }\end{array}$ & $\begin{array}{c}\text { Individual } \\
\text { Earnings (2006) }\end{array}$ & $\begin{array}{l}\text { Individual Earn. } \\
\text { Percentile (2006) }\end{array}$ & $\begin{array}{l}\text { Num. of Prop. } \\
\text { Crimes (2003) }\end{array}$ & $\begin{array}{l}\text { Num. of Drug } \\
\text { Sales (2003) }\end{array}$ & $\begin{array}{c}\text { Num. of } \\
\text { Arrests (2003) }\end{array}$ \\
\hline $\begin{array}{l}\text { Dropped out to work or } \\
\text { take care of family }\end{array}$ & $\begin{array}{l}-0.324 \\
(1.089)\end{array}$ & $\begin{array}{l}-1038 \\
(1643)\end{array}$ & $\begin{array}{l}-2.601 \\
(3.362)\end{array}$ & $\begin{array}{l}-0.031 \\
(0.190)\end{array}$ & $\begin{array}{c}0.358 \\
(0.582)\end{array}$ & $\begin{array}{c}0.127 \\
(0.101)\end{array}$ \\
\hline $\begin{array}{l}\text { Dropped out because } \\
\text { disliked school }\end{array}$ & $\begin{array}{c}-1.765 \\
(0.616)^{\star \star \star}\end{array}$ & $\begin{array}{c}-5329 \\
(1370)^{\star \star \star}\end{array}$ & $\begin{array}{c}-12.137 \\
(2.499)^{\star \star \star}\end{array}$ & $\begin{array}{c}0.146 \\
(0.255)\end{array}$ & $\begin{array}{c}1.103 \\
(0.566)^{\star \star}\end{array}$ & $\begin{array}{c}0.114 \\
(0.079)\end{array}$ \\
\hline $\begin{array}{l}\text { Dropped out for } \\
\text { behavioral reason }\end{array}$ & $\begin{array}{l}-0.693 \\
(1.049)\end{array}$ & $\begin{array}{c}-6340 \\
(1192)^{\star \star \star}\end{array}$ & $\begin{array}{c}-12.717 \\
(2.694)^{\star \star \star}\end{array}$ & $\begin{array}{c}0.341 \\
(0.334)\end{array}$ & $\begin{array}{c}1.346 \\
(0.537)^{\star \star \star}\end{array}$ & $\begin{array}{c}0.293 \\
(0.111)^{\star \star \star}\end{array}$ \\
\hline $\begin{array}{l}\text { Dropped out for other } \\
\text { "passive" reason }\end{array}$ & $\begin{array}{l}-0.604 \\
(0.648)\end{array}$ & $\begin{array}{c}-4858 \\
(1266)^{\star \star \star}\end{array}$ & $\begin{array}{c}-11.77 \\
(2.139)^{\star \star \star}\end{array}$ & $\begin{array}{c}0.134 \\
(0.230)\end{array}$ & $\begin{array}{c}0.405 \\
(0.376)\end{array}$ & $\begin{array}{c}0.422 \\
(0.250)^{*}\end{array}$ \\
\hline
\end{tabular}

Note: Sample for all specificaions consists of males who had valid AFQT scores and valid information on highest grade attended prior to the age of 19. Propensity score for each treatment obtained using probit extimates. "Untreated" group in each estimate are those who completed grade 12 but did not complete any higher grades. A gaussian kernel was used for deriving matching estimates. Characteristics used in the match include birth year dummies, region of residence dummies, race dummies, household income in 1997, dummy for living with two parents at age 12, dummy for living in urban area at age 12, dummy for mother giving birth as a teenager, dummy for reporting gangs in school at age 12, AFQT score, AFQT score squared, a dummy for high grades in 8th grade (A's and B's or better), a dummy for low grades in 8th grade (Mostly D's or lower), and a dummy for missing 8th grade grade information, a delinquency index from 1997, a dummy for smoking marijuana before age 16, and number of days of suspension before age 16. Bootstrapped Standard errors in parentheses. * significant at $10 \%$; ${ }^{* *}$ significant at $5 \%$; ${ }^{* *}$ significant at $1 \%$. 
Table 7 - Mean Background Characteristics For High School Dropouts by Dropout Reason

\begin{tabular}{|c|c|c|c|c|}
\hline Characteristic & $\begin{array}{c}\text { Dropped out to } \\
\text { work or take } \\
\text { care of family }\end{array}$ & $\begin{array}{l}\text { Dropped out } \\
\text { because did not } \\
\text { like school }\end{array}$ & $\begin{array}{c}\text { Dropped out due } \\
\text { to behavioral } \\
\text { problems }\end{array}$ & $\begin{array}{c}\text { Dropped out for } \\
\text { "other" passive } \\
\text { reasons }\end{array}$ \\
\hline Black & $\begin{array}{c}0.26 \\
(0.047)\end{array}$ & $\begin{array}{c}0.30 \\
(0.035) \\
{[0.57]}\end{array}$ & $\begin{array}{c}0.42 \\
(0.038) \\
{[0.01]^{\star \star \star}}\end{array}$ & $\begin{array}{c}0.41 \\
(0.031) \\
{[0.01]^{\star \star \star}}\end{array}$ \\
\hline Hispanic & $\begin{array}{c}0.43 \\
(0.053)\end{array}$ & $\begin{array}{c}0.30 \\
(0.035) \\
{[0.06]^{\star}}\end{array}$ & $\begin{array}{c}0.28 \\
(0.035) \\
{[0.02]^{\star \star}}\end{array}$ & $\begin{array}{c}0.23 \\
(0.027) \\
{[0.00]^{\star \star \star}}\end{array}$ \\
\hline Household Income (1997) & $\begin{array}{l}19,645 \\
(1787)\end{array}$ & $\begin{array}{l}25,865 \\
(1947) \\
{[0.02]^{\star \star}}\end{array}$ & $\begin{array}{c}30,795 \\
(2976) \\
{[0.00]^{\star \star \star}}\end{array}$ & $\begin{array}{c}30,264 \\
(2069) \\
{[0.00]^{\star \star \star}}\end{array}$ \\
\hline Lived with two parents at age 12 & $\begin{array}{c}0.26 \\
(0.047)\end{array}$ & $\begin{array}{c}0.23 \\
(0.032) \\
{[0.57]}\end{array}$ & $\begin{array}{c}0.26 \\
(0.034) \\
{[0.99]}\end{array}$ & $\begin{array}{c}0.26 \\
(0.028) \\
{[0.97]}\end{array}$ \\
\hline Lived in Urban area at age 12 & $\begin{array}{c}0.52 \\
(0.054)\end{array}$ & $\begin{array}{c}0.65 \\
(0.037) \\
{[0.04]^{\star \star}}\end{array}$ & $\begin{array}{c}0.60 \\
(0.038) \\
{[0.18]}\end{array}$ & $\begin{array}{c}0.60 \\
(0.031) \\
{[0.20]}\end{array}$ \\
\hline Mother gave birth as teenager & $\begin{array}{c}0.16 \\
(0.039)\end{array}$ & $\begin{array}{c}0.22 \\
(0.032) \\
{[0.23]}\end{array}$ & $\begin{array}{c}0.16 \\
(0.028) \\
{[0.91]}\end{array}$ & $\begin{array}{c}0.18 \\
(0.024) \\
{[0.72]}\end{array}$ \\
\hline Gangs in school (1997) & $\begin{array}{c}0.57 \\
(0.053)\end{array}$ & $\begin{array}{c}0.55 \\
(0.038) \\
{[0.70]}\end{array}$ & $\begin{array}{c}0.63 \\
(0.037) \\
{[0.36]}\end{array}$ & $\begin{array}{c}0.49 \\
(0.032) \\
{[0.16]}\end{array}$ \\
\hline AFQT score & $\begin{array}{c}0.21 \\
(0.021)\end{array}$ & $\begin{array}{l}0.21 \\
(0.15) \\
{[0.71]}\end{array}$ & $\begin{array}{c}0.19 \\
(0.014) \\
{[0.62]}\end{array}$ & $\begin{array}{c}0.24 \\
(0.014) \\
{[0.22]}\end{array}$ \\
\hline $\begin{array}{l}\text { High Grades 8th Grade } \\
\text { (A's and B's or better) }\end{array}$ & $\begin{array}{c}0.08 \\
(0.030)\end{array}$ & $\begin{array}{c}0.06 \\
(0.018) \\
{[0.52]}\end{array}$ & $\begin{array}{c}0.10 \\
(0.23) \\
{[0.69]}\end{array}$ & $\begin{array}{c}0.12 \\
(0.021) \\
{[0.32]}\end{array}$ \\
\hline $\begin{array}{l}\text { Low Grades 8th Grade } \\
\text { (Mostly D's or lower) }\end{array}$ & $\begin{array}{c}0.25 \\
(0.047)\end{array}$ & $\begin{array}{c}0.31 \\
(0.036) \\
{[0.32]}\end{array}$ & $\begin{array}{c}0.30 \\
(0.036) \\
{[0.33]}\end{array}$ & $\begin{array}{c}0.36 \\
(0.031) \\
{[0.05]}\end{array}$ \\
\hline Delinquency Index & $\begin{array}{c}2.17 \\
(0.213)\end{array}$ & $\begin{array}{c}2.43 \\
(0.177) \\
{[0.36]}\end{array}$ & $\begin{array}{c}2.96 \\
(0.205) \\
{[0.01]^{\star \star \star}}\end{array}$ & $\begin{array}{c}2.16 \\
(0.148) \\
{[0.96]}\end{array}$ \\
\hline Smoked marijuana $<16$ yrs old & $\begin{array}{c}0.26 \\
(0.047)\end{array}$ & $\begin{array}{c}0.30 \\
(0.035) \\
{[0.50]}\end{array}$ & $\begin{array}{c}0.41 \\
(0.038) \\
{[0.02]^{\star \star}}\end{array}$ & $\begin{array}{c}0.24 \\
(0.027) \\
{[0.68]}\end{array}$ \\
\hline Days of suspension $<16$ yrs old & $\begin{array}{l}17.53 \\
(4.71)\end{array}$ & $\begin{array}{l}16.43 \\
(2.19) \\
{[0.83]}\end{array}$ & $\begin{array}{c}30.58 \\
(4.63) \\
{[0.05]^{\star \star}}\end{array}$ & $\begin{array}{l}16.32 \\
(1.86) \\
{[0.81]}\end{array}$ \\
\hline
\end{tabular}

Note: Standard errors in parentheses. Terms in brackets show p-value of test of equality between coefficient and counterpart for the "dropped out to work..." group. * significant at $10 \%$; ** significant at $5 \%$; ${ }^{\star \star *}$ significant at $1 \%$. 
Table 8 - Labor Market Work for High School Dropouts over First Thee Months After Dropping Out (By Dropout Reason)

\begin{tabular}{cccc}
$\begin{array}{c}\text { Dropped out to } \\
\text { work or take } \\
\text { care of family }\end{array}$ & $\begin{array}{c}\text { Dropped out } \\
\text { because did not } \\
\text { like school }\end{array}$ & $\begin{array}{c}\text { Dropped out due } \\
\text { to behavioral } \\
\text { problems }\end{array}$ & $\begin{array}{c}\text { Dropped out for } \\
\text { "other" passive } \\
\text { reasons }\end{array}$ \\
\hline
\end{tabular}
Avg hrs/wk working first three
months after dropping out

Didn't work for first three months after dropping out

$$
25.11
$$

0.18

(0.04)

16.00
$(1.47)$
$[0.00]^{\star \star \star}$

0.40

$(0.04)$

$[0.00]^{\star *}$
16.31
$(1.64)$
$[0.00]^{\star \star *}$

0.35

$(0.04)$

$[0.00]^{\star \star \star}$
16.54

(1.28)

$[0.00]^{\star \star \star}$

0.28

(0.03)

$[0.05]^{\star \star}$

Note: Standard errors in parentheses. Terms in brackets show p-value of test of equality between coefficient and counterpart for the "dropped out to work..." group. * significant at 10\%; ** significant at 5\%; *** significant at $1 \%$. 